\title{
IDEAS \& Cross-boundary cooperation: A mechanism for INNOVATIONS sustaining ecosystem services from private lands
}

Mark Rickenbach, Lisa A. Schulte, David B. Kittredge, William G. Labich, and Doug J. Shinneman

T he need to conserve and manage at and across multiple spatial scales to sustain critical ecosystem services (e.g., food, fiber, amenities, clean water) is an accepted tenet of modern resource management (MEA 2003; Palmer et al. 2004; Foley et al. 2005). Moreover, this "multiscalar" perspective is evident in plans and, in some cases, practice on public lands and some large private landholdings (Schulte et al. 2006). However, most private lands-particularly those in relatively small landholdings $<101$ ha $(<250$ ac) — present a significant challenge to extending this perspective for two reasons:

1. Private landownership is a dominant part of our land base. Ten million individuals and families own over $35 \%$ of all US forestlands, with concentrations exceeding $85 \%$ in parts of the eastern United States (Butler 2008). In addition, many ecologically important sites are on, span, or are connected to these small private landholdings (Scott et al. 2006; Ruhl et al. 2007).

2 . The perceptions, rights, policies, and institutions associated with private land are entrenched (willingly or not) in an "ownership-centric" framework that is largely driven by and evaluated using parcel-scale metrics (e.g., number of plans, conservation easements).

Researchers and practitioners have increasingly emphasized the need for

Mark Rickenbach is a professor and extension specialist in the Department of Forest \& Wildlife Ecology, University of Wisconsin-Madison, Madison, Wisconsin. Lisa A. Schulte is an associate professor in the Department of Natural Resource Ecology and Management, lowa State University, Ames, lowa. David B. Kittredge is a professor in the Department of Environmental Conservation, University of Massachusetts Amherst, Amherst, Massachusetts, and a policy analyst for Harvard Forest, Harvard University, Petersham, Massachusetts. William G. Labich is a regional conservationist at Highstead, Redding, Connecticut. Doug J. Shinneman was a postdoctoral scientist at The Nature Conservancy, Minneapolis, Minnesota, at the time of writing this article; he is currently a research fire ecologist for the Forest and Rangeland Ecosystem Science Center, US Geological Survey, Boise, Idaho. cooperative, multiscalar management strategies that span property boundaries (Hein et al. 2006; Goldman et al. 2007; de Groot et al. 2009), but practice and policy have lagged.

Our purpose is to advance greater multiscalar thinking and action in the provisioning of ecosystem services from private lands. To move in this direction, social and institutional factors that shape private land management and policy are central considerations. Notably, the concept of cross-boundary cooperation (XBC) as envisioned for forest ecosystems, primarily in the United States and Scandinavia, holds promise. Broadly defined, $\mathrm{XBC}$ is voluntary behavior whereby one or more landowners account for the plans and practices on adjacent and/or nearby properties. To advance this multiscalar, cross-boundary perspective requires two elements. First, we concisely synthesize past XBC research, identifying leverage points for and roadblocks to its implementation. Second, we propose the cultivation of key social and institutional "ingredients" to promote more widespread experimentation and application. We posit that these ingredients are essential to fostering cross-boundary cooperation. However, before we advance these elements, we address two contextual pieces: (1) background on US private forests, their disposition, and use; and (2) a more expansive and workable definition of XBC.

Private Forests: A Primer. Private forests, particularly those held in relatively small landholdings, are defining landscape characteristics. For example, the southern New England landscape is a patchwork of thousands of small landholdings that from the sky appear as a continuous forest blanket. These lands are essential economic and sociocultural resources that benefit landowners and rural communities. US timber supply is sourced predominantly (>50\%) from small private landholdings. In addition, these lands are critical for amenity- and tourism-based economies (Marcouiller and Mace 1999). Markets for ecosystem services are increasingly looking to private forests as carbon sinks and for watershed services. Private forests also account for significant reserves of critical habitat for endangered species and biodiversity.

One factor that substantively challenges multiscalar management of private forests and other natural ecosystems is recent and ongoing parcelization: the subdivision (i.e., fragmentation) of large ownerships into smaller ones (Gobster and Rickenbach 2004). In 2003, the average forest landholding size in the United States was 15 ha $(38 \mathrm{ac})$, a nearly $10 \%$ reduction from 1993 (Butler and Leatherberry 2004). Parcelization reflects a generational shift in landownership (i.e., inheritance, sale) and purchasing decisions by amenity-seeking new landowners. However, detrimental ecological impacts result, such as increased rates of habitat fragmentation and conversion to more developed uses (Theobald 2001). Hansen et al. (2005) have shown that even low-density residential development, a typical result of parcelization, often severely compromises the habitat quality for biodiversity.

Motivations for private forest landownership and management also challenge the sustainable production of ecosystem services in many parts of the United States. Unlike farmers with whom they are often compared, most woodland owners live on the land, not off it. Reasons for landownership vary, but they are nearly always noneconomic and reflect desires for recreation, aesthetics, and privacy (Butler 2008; Kendra and Hill 2005). At the same time, landowners recognize that trees have value and periodically will cut timber, usually in response to solicitations from timber market actors (e.g., sawmills, loggers, foresters). Even for the subset of landowners who actively manage their land, economies of scale usually limit what they can accomplish (Schulte et al. 2008). It is fair to say that most landowners are reactive, and their forestry practices typically are not part of planned management, nor are they professionally assisted (Butler 2008). From a landscape perspec- 
tive, small forest landholdings are managed in a haphazard ownership-centric way that often lacks any connection to multiscalar ecological principles.

Cross-Boundary Cooperation: A Working Definition. Yet, maintaining the flow of ecosystem services necessitates a multiscalar perspective: one where individual landholdings are viewed as part of a broader social, economic, and ecological landscape (Kurttila et al. 2002). Cross-boundary cooperation among landowners represents one approach by which multiscalar thinking and outcomes can be promoted on parcelized landscapes (Kittredge 2005; Schulte et al. 2008). In providing a definition, there are two terms: "cross-boundary" and "cooperation." Most simplistically, cross-boundary is just that, cooperation among adjacent landowners. However, cooperation among "near neighbors" (e.g., two parcels separated by one in between) can also accrue benefits by taking advantage of increasing economies of scale (Schulte et al. 2008). Cooperation is, perhaps, the trickier term given the various social science disciplines that explore it. For our purposes, we rely on a definition by Yaffee (1998), which defines cooperation as an escalating continuum of commitment ranging from awareness and information sharing to collaboration in planning and practice implementation. Awareness and information sharing may seem to be weak minimum thresholds, but they do represent substantial steps toward a multiscalar perspective in managing small landholdings compared to what exists today.

\section{CROSS-BOUNDARY COOPERATION: PAST RESEARCH}

In recent years, numerous studies have explored the feasibility of XBC, and these can be classified into three broad areas that form the basis of our review: (1) landscape feasibility and impacts, (2) landowner interest and receptivity, and (3) promotion of XBC by the institutional environment.

Landscape Feasibility and Impacts. Coordinating land management within landscapes composed of small landholdings expands the range of ecosystem services that might be provided (Öhman and Lämås 2003). Intuitively, this makes sense for at least three reasons. First, coordination increases the available land area on which multiple objectives can coexist (Kurttila and Pukkala 2003)_particularly those that may be incompatible (e.g., oldgrowth reserves and fiber production). Second, the scale of specific practices is not constrained by landholding size (Kittredge et al. 2006). Third, coordination may yield economies of scale that might make practices more financially attractive or possible (Schulte et al. 2008). However, optimization of diverse outcomes can be complicated and difficult in practice as not all landscape-scale objectives are compatible (Kurttila et al 2002; Atwell et al. 2010). Despite such challenges, XBC among landowners offers the potential to expand the provision of ecosystem services and produce ecologically beneficial patch configurations (figure 1)-features that are often most at risk under traditional ownership-centric approaches.

Landowner Interest and Receptivity. Cross-boundary cooperation is not a widespread phenomenon (Kittredge 2005; Rickenbach and Jahnke 2006). This is not to suggest that landowners are unreceptive or disinterested. Numerous surveys show that landowners value landscapescale outcomes (Brunson et al. 1996; Raedeke et al. 2001; Belin et al. 2005) and are willing to consider cross-boundary approaches (Finley et al. 2006; Rickenbach et al. 2006; Stevens et al. 1999). However, landowners do not necessarily perceive a personal benefit, and other factors may intervene. As such, a more nuanced perspective is necessary (Atwell et al. 2009; Gass et al. 2009).

Regardless of its extent, cooperation is fundamentally a social enterprise that requires landowners to engage with a new suite of actors (i.e., neighbors, resource managers) and perspectives in decision making. Trust among those involved is critically important (Rickenbach and Reed 2002; Bergmann and Bliss 2004; Wagner et al. 2007)—a potential challenge in places where landowners tend not to know their neighbors (Rickenbach and Kittredge 2009). Moreover, successful cooperation requires shared values and shared purpose, which are not synonymous (Rickenbach and Reed 2002;
Gass et al. 2009). While landowners may share similar broad values and reasons for owning their land (e.g., wildlife, nature, privacy), these do not necessarily translate into specific shared objectives (e.g., grouse habitat, savanna restoration, visual barriers) or knowledge as to the compatibility of different objectives as applied on the land (e.g., clearcutting, burning, tree planting).

Institutional Environment. Policies and organizations can support XBC by promoting and supporting landowner decision making and action. Of specific interest have been two types of outcomes: spatial targeting and aggregation (Goldman et al. 2007; Ruhl et al. 2007; Secchi et al. 2008). For the former, the spatial arrangement of landscape elements is key to the production of a specific service (e.g., surface water quality is dependent on upstream land use) and depends on targeting resources toward specific places on the landscape (e.g., upstream riparian areas). The latter requires sufficient production of a good or service to have an impact (e.g., sufficient carbon storage to interest an aggregator). Institutional response in this case might offer agglomeration bonuses (i.e., incentives that scale higher with increased participation) to foster cooperation in meeting the minimum threshold (Parkhurst et al. 2002; Goldman et al. 2007). Key to any shift toward a more multiscalar perspective is the need to build collective capacity among landowners and others. Landowner associations (e.g., cooperatives, not for profits) that focus on specific goals-for instance, wood or wildlife habitat cooperatives - provide a means by which landowners could engage with one another and build cooperation (Kittredge 2003, 2005). Other organizations with broader participation may also be desirable - particularly when the outcomes are of interest to others in the community (e.g., hunting, water quality, open space). Formal groups provide a structure for communication, assembling people with similar philosophies or perspectives and build institutional memory and credibility, which in turn, foster cooperation (Rickenbach et al. 2005; van Gossum et al. 2005; Rickenbach 2009). Such associations are not widespread, but 


\section{Figure 1}

Plausible scenarios of status-quo and cross-boundary management on four 16 ha (40 ac) parcels. (a) Status-quo management in southwestern ponderosa pine forests on private lands in which only the owners of the lower-right property have adopted fireproofing techniques; their home is still at a high risk for burning because of a lack of fuels treatment on adjacent properties. (b) Under cross-boundary management, the fire risk has been lowered for three of the four homes as a result of the owners of the lower-right property talking to and working with their neighbors; the owners of the lower- and upper-left properties have also instituted firewise techniques around their homes, while the owner of the upper-right property has collaborated to reduce the fire risk to adjacent owners' homes, but has chosen not to institute these practices directly around her home. (c) Status-quo management of Midwestern oak forests where the owner of the lower-left property clearcuts the majority of his property in order to have a large enough timber volume to attract a buyer. (d) A cross-boundary scenario in which the owner of the lower-left property engages his neighbors on oak forest management and the timber sale; the owners of the lower-right and upper-left properties respectively clearcut and thin a portion of their forest, allowing an overall higher volume timber sale and the maintenance of more natural ecosystem boundaries. Visualizations courtesy of Drake Larsen, lowa State University.
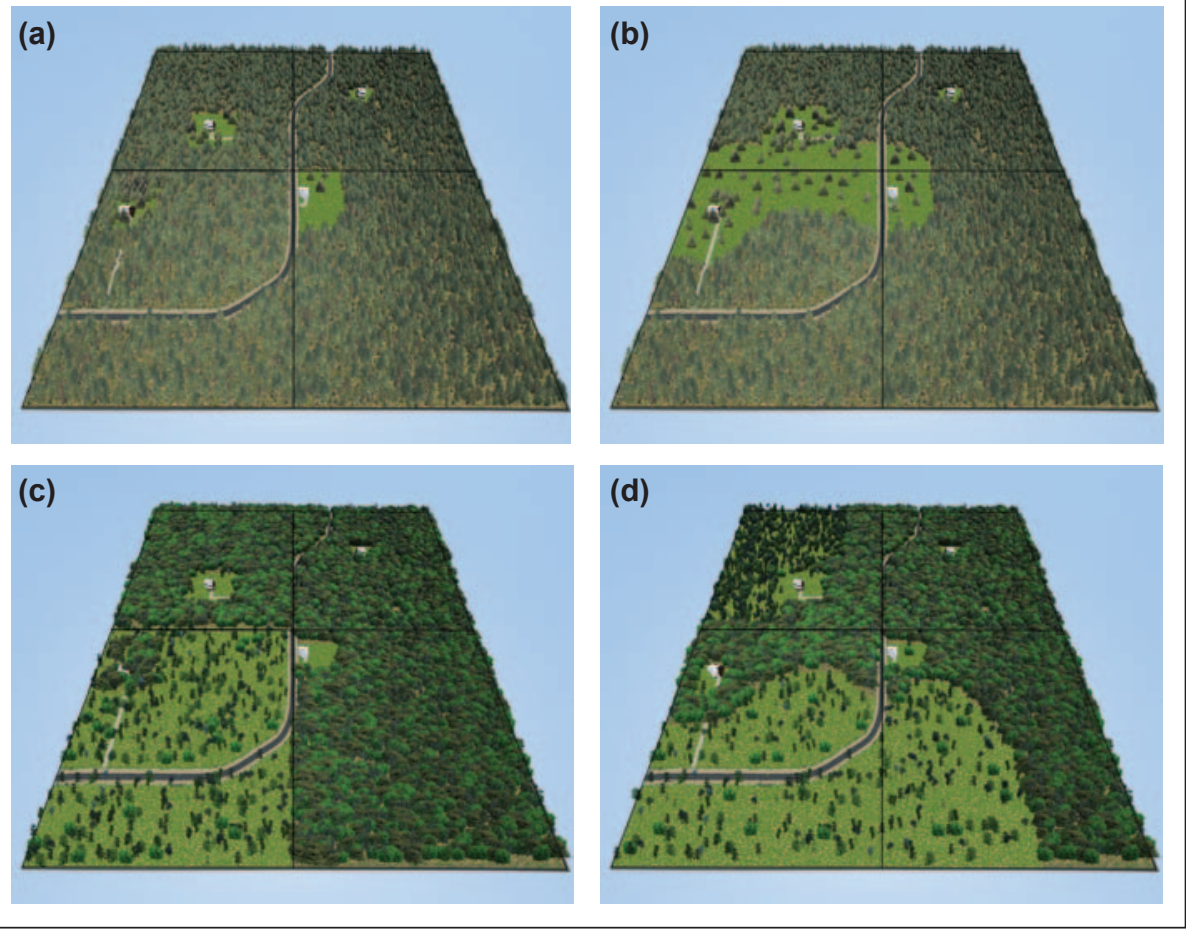

interest in them continues to grow (Blinn et al. 2007; Hull and Ashton 2008).

\section{CREATING A CROSS-BOUNDARY FUTURE}

Landowners are generally amendable to XBC, and individual, societal, and ecological benefits might arise from its application (figure 1). Currently, though, the practice of XBC is sporadic (Kittredge 2005; Rickenbach and Jahnke 2006). Lack of interest on the part of landowners is partly responsible, but the responsibility is not solely theirs. The institutional environment typically does not promote multiscalar thinking and action among foresters, government agencies, and watershed associations have come together to form regional conservation strategies to protect land from development. One successful example of such collaboration is the Blackfoot Challenge, which seeks to conserve open lands and working lands and to improve water quality in western Montana, (http://blackfootchallenge.org/). Landscape Conservation Cooperatives, tasked with climate adaptation and mitigation, (http://www.fws.gov/science/shc/ lcc.html) is another emerging model.

To assist these and foster broader adoption of multiscalar approaches on private lands, we suggest an approach comprised of three essential elements that landowners, resource managers, policymakers, and others might utilize: (1) willing landowners, (2) effective boundary spanners, and (3) sufficient institutional support. As we will outline further, these elements have implications for both policy and practice at multiple ecological and geopolitical scales.

Willing Landowners. By "willing" we mean those landowners who are aware of the potential benefits that might accrue through cooperation-personally, to neighbors, and to society. They also can commit their time, money, and/or effort to develop shared goals and a workable approach. Cross-boundary cooperation is voluntary and depends on having landowners share similar desired outcomes and paths toward those outcomes. At a public policy level, the ecosystem services that offer the best possibilities for success are those with broad benefits to private landowners, such as fire protection in dry western forests (figure $1 \mathrm{a}$ and $1 \mathrm{~b}$ ) or carbon sequestration that rewards modest or limited active management of native ecosystems. At community scales, landowners and, for example, land trusts may share land protection interests that maintain a local aesthetic (figure $1 \mathrm{c}$ and $1 \mathrm{~d}$ ). In practice, shared outcomes might be easily agreeable, but the pathway to obtaining them may not. For example, neighboring landowners may all agree that trail-based recreation (e.g., county snowmobile trail networks) is beneficial to the community but might not agree on who should pay for trail development, on whose land to place a bridge, or who will provide 
maintenance. Cultivating shared management goals and approaches-particularly those often removed from landowners' everyday lives (e.g., reducing fuel loads, maintaining late-successional habitats) can be time consuming and require as much work as implementing the practice itself. Hence, the people facilitating such outcomes-boundary spanners-need the aptitude, latitude, and resources to engage willing landowners in substantive, up-front discourse.

Boundary Spanners. Boundary spanners are those individuals that create the connections among others that allow new and collaborative efforts to occur (Aldrich and Herker 1977). Landowners may not understand the ecological context or need for certain practices or even know their neighbors. In such situations, other actors need to facilitate knowledge transferlink landowners to technical, financial, or other resources-and otherwise support cooperative behavior. Resource managers are logically positioned to be boundary spanners, and in some cases they already fill this role (Ruseva 2010). However, boundary spanners can come from a broader set of actors with an interest in landscapescale outcomes. Indeed, resource managers can, in some cases, be counterproductive to encouraging landowner cooperation as they may be seen as pushing a specific agenda or interest or lacking credibility (Rickenbach et al. 2005; Gass et al. 2009). As such, others in the local community (e.g., peer landowner, soil and water conservation district board member, educator at the local nature center, real estate agent) may be better positioned. What is important is that the boundary spanner be seen as an honest broker who can link (either directly or indirectly) willing landowners and other community members with the resources for action. The skills needed for this role differ from how we typically train resource managers, but effective boundary spanners have social and facilitation skills allowing them to effect multiscalar change.

Institutional Support. In some cases, the right ecological opportunity may align with the right willing landowners and boundary spanners. In most cases, additional catalysts are needed to propel cooperation, such as institutional support.
This can (and often does) include resources (i.e., dollars, time, knowledge) and infrastructure (i.e., agency support, flexible policies, monitoring tools). In moving toward multiscalar approaches, it is easy to suggest that new resources are needed, but we believe that reallocation is probably the more prudent direction. For example, incentive programs could be altered to favor practices consistent with landscape outcomes as opposed to those that meet only (or primarily) landowner objectives. Yet multiscalar approaches may require infrastructural support beyond what is typical for ownership-centric management (Wolf and Hufnagl-Eichiner 2007). The status quo delivery of ecological information to private landowners is limited-data often reside in a management plan that covers an individual landholding, and information on the broader landscape in which a parcel resides is most often absent or superficial. Cross-boundary efforts show success when a boundary spanner can offer or link to key infrastructural support, including (1) the assemblage and maintenance of geographic databases, (2) models that can project the delivery of ecosystem services, and (3) other technical experts that can further assist landowners to develop and implement landscape-level management.

Currently, most economic incentives (e.g., cost share payments, conservation easements) and similar approaches (e.g., organic certification, forest certification) are typically ownership-centric with few mechanisms for encouraging aggregation or collective action (Parkhurst et al. 2002; Goldman et al. 2007; Secchi et al. 2008). Until alternatives are available, boundary spanners must facilitate cooperation, while also pushing institutional change. For example, the economies of scale associated with carbon sequestration have assured that aggregators will play a significant role in landowners' participation in carbon markets (Current et al. 2007), but as more aggregation occurs, new mechanisms and policies will emerge.

Three caveats should not be overlooked:

1. Not every management practice or program must be multiscalar, but greater balance should be a goal. We realize that cooperation comes with its own set of challenges and costs, but recognize that landscape outcomes on private lands will continue to be a sporadic and haphazard affair without explicit investments.

2. We are not recommending large, new, public investments, but rather a refocusing of existing tools and assets toward multiscalar ecological and societal outcomes. Existing policies, programs, and investments are poised to build the needed social and technical capacity to foster cross-boundary cooperation. For example, dollars and technical expertise that are supporting "equal access" (i.e., walk-in and signup) conservation programs at present could be shifted to target locations that provide disproportionately higher levels of ecosystem services (Secchi et al. 2008). Furthermore, incentive payments could be scaled according to the number of participants or total area affected (Goldman et al. 2007).

3 . To refocus current efforts, a new multiscalar dialogue is needed.Various public agencies, private entities, and landowner associations have an interest in broad-scale environmental outcomes, but they only hazily understand their shared goals and interests. Greater coordination among those seeking to effect outcomes on private lands could yield more efficient and effective outcomes, along with improving relationships with private landowners - the ultimate arbiters of practices on their lands.

\section{CONCLUSION}

Overall, we believe that a landscape with functional, multiscalar XBC would differ dramatically from one with the status quo of ownership-centric conservation effort (table 1) (figure 1). As we have noted, elements of XBC have organically formed among public and private landowners, land trusts, and others with the assistance of varied boundary spanners. In some cases, resources have been available to support such efforts, while others manage on a very small budget. There have been both successes and failures. For reasons already enumerated, we cannot abandon or even subordinate conservation efforts on private lands. We need broad and 


\section{Table 1}

\section{Key differences between status-quo and cross-boundary land management.}

\begin{tabular}{|c|c|c|}
\hline & Status-quo or "ownership-centric" management & Cross-boundary, multiscalar management \\
\hline Expected outcome & $\begin{array}{l}\text { Parcel-scale impacts; aggregated impacts are } \\
\text { considered primarily in geopolitical contexts }\end{array}$ & Landscape-scale impacts; allows for synergies from cooperation \\
\hline What & $\begin{array}{l}\text { Outreach, technical assistance, and/or subsidies to } \\
\text { individual landowners, usually involving limited targeting }\end{array}$ & $\begin{array}{l}\text { Outreach, technical assistance, and/or subsidies target specific } \\
\text { geographic areas }\end{array}$ \\
\hline Who & $\begin{array}{l}\text { Individual landowners potentially in consultation with } \\
\text { professionally trained public sector employees (e.g., } \\
\text { USDA Natural Resource Conservation Service, state } \\
\text { department of natural resources, county conservation) }\end{array}$ & $\begin{array}{l}\text { A multiactor approach that more fully includes landowners, } \\
\text { private nongovernmental organizations (e.g., watershed } \\
\text { association, land trust, wildlife or recreation club), public agencies, } \\
\text { motivated volunteers, and other professionals }\end{array}$ \\
\hline Methods & $\begin{array}{l}\text { Professionally trained public sector employees work } \\
\text { on a landowner-by-landowner, visit-by-visit, } \\
\text { property-by-property basis }\end{array}$ & $\begin{array}{l}\text { Boundary spanners facilitate information sharing and transfer } \\
\text { between peer landowners }\end{array}$ \\
\hline Funding & $\begin{array}{l}\text { Public and private philanthropic funds subsidize } \\
\text { individual landowner behaviors or actions (e.g., federal } \\
\text { farm bill programs) to pay for the purchase of scattered } \\
\text { conservation easements or the development of } \\
\text { individual management plans or access roads }\end{array}$ & $\begin{array}{l}\text { Public and private philanthropic funds underwrite local } \\
\text { organizations or individuals to provide spanning functionality; } \\
\text { funds from the provision of ecosystem services (e.g., carbon } \\
\text { credits, clean water credits, rare species credits) underwrite this } \\
\text { spanner/network/counseling functionality }\end{array}$ \\
\hline Philosophy & $\begin{array}{l}\text { Technical assistance is a primary driver; experts deliver } \\
\text { advice and money down to individual landowners with } \\
\text { success equated to more practices implemented } \\
\text { on individual properties }\end{array}$ & $\begin{array}{l}\text { Varying levels of cross-boundary cooperation implemented by } \\
\text { landowners in a landscape; technical assistance is brought in } \\
\text { on an as-needed basis, and success is measured by overall } \\
\text { landscape impact, such as improved landscape functionality }\end{array}$ \\
\hline Scale & Individual ownerships & $\begin{array}{l}\text { Habitat, watersheds, drainages, ecoregions, or other logical } \\
\text { socioecological units }\end{array}$ \\
\hline
\end{tabular}

innovative policy changes that stress and foster a multiscalar worldview and cooperative behavior that supports it. Without these, the ability of private lands to provision ecosystem services will continue to decline, and more drastic, controversial, and expensive approaches will be required to restore them in the future.

\section{ACKNOWLEDGEMENTS}

Initial discussions and work on this manuscript were the result of a working meeting at the Harvard Forest, Petersham, Massachusetts, of the authors financed by USDA Forest Service Northern Research Station (Joint Venture Agreement 04-JV-11231300-018). The working meeting coincided with the lead author's time as a Bullard Fellow at the Harvard Forest.

\section{REFERENCES}

Alrich, H., and D. Herker. 1977. Boundary spanning roles and organization structure. The Academy of Management Review 2:217-230.

Atwell, R.C., L.A. Schulte, and L.M. Westphal. 2009. Landscape, community, and countryside: linking biophysical and social scales in U.S. Corn Belt conservation initiatives. Landscape Ecology 24:791-806.

Atwell, R.C., L.A. Schulte, and L.M. Westphal. 2010. How to build multifunctional agricultural land- scapes in the U.S. Corn Belt: Add perennials and partnerships. Land Use Policy 27:1082-1090.

Belin, D.L., D.B. Kittredge, T.H. Stevens, D.C. Dennis, C.M. Schweik, and B.J. Morzuch. 2005. Assessing private forest owner attitudes toward ecosystembased management. Journal of Forestry 103: 28-35. Bergmann, S.A., and J.C. Bliss. 2004. Foundations of XBC: Resources management at the publicprivate interface. Society and Natural Resources 17:377-393.

Blinn, C.R., P.J. Jakes, and M. Sakai. 2007. Forest Landowner Cooperatives in the United States: A Local Focus for Engaging Landowners. Journal of Forestry 105:245-251.

Brunson, M.W., D.T. Yarrow, S.D. Roberts, D.C. Guynn Jr, and M.R. Kuhns. 1996. Nonindustrial private forest owners and ecosystem management: Can they work together? Journal of Forestry 94:14-21.

Butler, B.J. 2008. Family forest owners of the United States, 2006. General Technical Report NRS27. Newtown Square, PA: USDA Forest Service Northern Research Station.

Butler BJ and Leatherberry EC (2004) America's family forest owners. Journal of Forestry 102:4-9. Current, D., K. Scheer, J. Harting, D. Zamora, and L. Ulland. 2007. A landowner's guide to carbon sequestration credits. St. Paul, MN:
Central Minnesota Regional Sustainable Development Partnership.

de Groot, R.S., J.R.M. Alkemade, L. Braat, L. Hein, and L. Willemen. 2009. Challenges in integrating the concept of ecosystem services and values in landscape planning, management and decision making. Ecological Complexity 7:260-272.

Finley, A., D. Kittredge, T. Stevens, C. Schweik, and D. Dennis. 2006. Interest in cross-boundary cooperation: Identification of distinct types of private forest owners. Forest Science 52:10-22.

Foley, J.A., R. DeFries, G.P. Asner, C. Barford, G. Bonan, S.R. Carpenter, F.S. Chapin, M.T. Coe, G.C. Daily, H.K. Gibbs, J.H. Helkowski, T. Holloway, E.A. Howard, C.J. Kucharik, C. Monfreda,J.A. Patz, I.C. Prentice, N. Ramankutty, and P.K. Snyder. 2005. Global consequences of land use. Science 309:570-574.

Foster, D.R., D.B. Kittredge, B. Donahue, G. Motzkin, D. Orwig, A. Ellison, B. Hall, B. Colburn, and A. D'Amato. 2005. Wildlands and woodlands: A 100-year vision for the forests of Massachusetts. Petersham, MA: Harvard Forest paper. http:// www.wildlandsandwoodlands.org.

Gass, R.J., M. Rickenbach, L.A. Schulte, and K. Zeuli. 2009. Cross-boundary coordination on forested landscapes: Investigating alternatives for implementation. Environmental Management 43:107-117. 
Gobster, P.H., and M.G. Rickenbach. 2004. Private forestland parcelization and development in Wisconsin's Northwoods: Perceptions of resource-oriented stakeholders. Landscape and Urban Planning 69:165-182.

Goldman, R.L., B.H. Thompson, and G.C. Daily. 2007. Institutional incentives for managing the landscape: Inducing cooperation for the production of ecosystem services. Ecological Economics 64:333-343.

Hansen, A.J., R.L. Knight, J.M. Marzluff, S. Powell, K. Brown, P.H. Gude, and K. Jones. 2005. Effects of exurban development on biodiversity: patterns, mechanisms, and research needs. Ecological Applications 15:1893-1905.

Hein, L., K. van Koppen, R.S. de Groot, E.C. van Ierland. 2006. Spatial scales, stakeholders and the valuation of ecosystem services. Ecological Economics 57:209-228.

Hull, R.B., and S. Ashton. 2008. Forest cooperatives revisited. Journal of Forestry 106:100-105.

Kendra, A., and R.B. Hull. 2005. Motivations and behaviors of new forest owners in Virginia. Forest Science 51:142-154.

Kittredge, D.B. 2003. Private forestland owners in Sweden: Large-scale cooperation in action. Journal of Forestry 101:41-46.

Kittredge, D.B. 2005. The cooperation of private forest owners on scales larger than one individual property: International examples and potential application in the United States. Forest Policy and Economics 7:671-688.

Kittredge, D.B., K. Clark, M. Ohmann, P. Huckery, and T. French. 2006. Protection of habitat for state-listed rare flora and fauna in Massachusetts during timber harvesting. Natural Areas Journal 26:198-207.

Kurttila, M., and T. Pukkala. 2003. Combining holding-level economic goals with spatial landscape-level goals in the planning of multiple ownership forestry. Landscape Ecology 18:529-541.

Kurttilaa, M., J. Uutterab, S. Mykra, S. Kurki, and T. Pukkala. 2002. Decreasing the fragmentation of old forests in landscapes involving multiple ownership in Finland: Economic, social and ecological consequences. Forest Ecology and Management 166:69-84.

Marcouiller, D., and T. Mace. 1999. Forests and regional development: Economic impacts of woodland use for recreation and timber in Wisconsin. Publication G3964. Madison, WI: University of Wisconsin-Extension Cooperative Extension Service.

Matson, J.K. 2009. Wisconsin's Working Lands: Securing Our Future. Wisconsin Lawyer 82(12). http://www.wisbar.org/AM/Template.
cfm?Section $=$ Wisconsin_Lawyer\&template $=$ / $\mathrm{CM} /$ ContentDisplay.cfm\&contentid $=88733$.

MEA (Millennium Ecosystem Assessment). 2005. Millennium ecosystem assessment. http://www. millenniumassessment.org/en/index.aspx.

Noss, R.F., J.F. Franklin, W.L. Baker, T. Schoennagel, and P.B. Moyle. 2006. Managing fire-prone forests in the western United States. Frontiers in Ecology and the Environment 4:481-487.

Öhman, K., and T. Lämås. 2003. Clustering of harvest activities in multi-objective long-term forest planning. Forest Ecology and Management 176:161-171.

Palmer, M., E. Bernhardt, E. Chornesky, S. Collins, A. Dobson, C. Duke, B. Gold, R. Jacobson, S. Kingsland, R. Kranz, M. Mappin, M.L. Martinez, F. Micheli, J. Morse, M. Pace, M. Pascual, S. Palumbi, O.J. Reichman, A. Simons, A. Townsend, and M. Turner. 2004. Ecology for a crowded planet. Science 304:1251-1252.

Parkhurst, G.M., J.F. Shogren, C. Bastian, P. Kivi, J. Donner, and R.B.W. Smith. 2002.Agglomeration bonus: An incentive mechanism to reunite fragmented habitat for biodiversity conservation. Ecological Economics 41:305-328.

Raedeke, A.H., J.S. Rikoon, and C.H. Nilon. 2001. Ecosystem management and landowner concern about regulations: A case study in the Missouri Ozarks. Society and Natural Resources 14:741-759.

Rickenbach, M.G., and A.S. Reed. 2002. Crossboundary cooperation in a watershed context: The sentiments of private forest landowners. Environmental Management 30:584-594

Rickenbach, M., and A.D. Janhke. 2006. Wisconsin private sector foresters' involvement in nonindustrial private forestland cross-boundary forestry practices. Northern Journal of Applied Forestry 23:100-105.

Rickenbach, M., K. Zeuli, and E. Sturgess-Cleek. 2005. Despite failure: The emergence of "new" forest owners in private forest policy in Wisconsin, USA. Scandinavian Journal of Forestry Research 20:503-513.

Rickenbach, M.G., R.P. Guries, and D.L. Schmoldt. 2006. Membership matters: Comparing members and non-members of NIPF owner organizations in southwest Wisconsin, USA. Forest Policy and Economics 8:93-103.

Rickenbach, M. 2009. Serving members and reaching others: The performance and social networks of a landowner cooperative. Forest Policy and Economics 11:593-599

Rickenbach, M., and D.B. Kittredge. 2009. Time and distance: Comparing motivations among forest landowners in New England. Small-Scale Forestry 8:95-108.
Ruhl, J.B., S.E. Kraft, and C.L. Lant. 2007. The law and policy of ecosystem services. Washington, DC: Island Press.

Ruseva, T. 2010. The role of district foresters in collaborative management: Implications for private forest governance. Consortium on Collaborative Governance Doctoral Conference, University of Southern California, Los Angeles, CA, April 9-10, 2010. http://www.usc.edu/schools/sppd/ bedrosian/private/ccg_doctoral_conf_papers/ Ruseva_CCG_Paper_April2010.pdf

Schulte, L.A., R.J. Mitchell, M.L. Hunter Jr., J.F. Franklin, R.K. McIntyre, and B.J. Palik. 2006. Evaluating the conceptual tools for forest biodiversity conservation and their implementation in the U.S. Forest Ecology and Management 232:1-11.

Schulte, L.A., M. Rickenbach, and L.C. Merrick. 2008. Ecological and economic benefits of crossboundary coordination among private forest owners. Landscape Ecology 23:481-496.

Scott, J.M., D.D. Gobel, and F.W. Davis (Eds). 2006. The Endangered Species Act at Thirty,Volume 2: Conserving biodiversity in human-dominated landscapes. Washington, DC: Island Press.

Secchi, S., J. Tyndall, L.A. Schulte, and H. Asbjornsen. 2008. High crop prices and conservation: Raising the stakes. Journal of Soil and Water Conservation 63:68A-73A.

Stevens, T.H., D. Dennis, D. Kittredge, and M. Rickenbach. 1999. Attitudes and preferences toward co-operative agreements for management of private forestlands in the northeastern United States. Journal of Environmental Management 55:81-90.

Theobald, D.M. 2001. Land-use dynamics beyond the American urban fringe. The Geographical Review 91: 544-564.

van Gossum P, S. Luyssaert, I. Serbruyns, and F. Mortier. 2005. Forest groups as support to private forest owners in developing close-to-nature management. Forest Policy and Economics 7:589-601.

Wagner, M.W., U.P. Kreuter, R.A. Kaiser, and R.N. Wilkins. 2007. Collective action and social capital of wildlife management associations. Journal of Wildlife Management 71:1729-1738.

Wolf, S.A., and S. Hufnagl-Eichiner. 2007. External resources and development of forest landowner collaboratives. Society and Natural Resources 20:675-688.

Yaffee, S.L. 1998. Cooperation: a strategy for achieving stewardship across boundaries. In Stewardship across Boundaries, eds. R.L. Knight and P. Landres. Washington, DC: Island Press. 